\title{
Women in agriculture: Key developments under eleventh five year plan and thrust areas of the twelfth plan
}

\author{
AMTUL WARIS \\ ICAR-Indian Institute of Rice Research, HYDERABAD (TELANGANA) INDIA \\ (Email : amtul.waris@gmail.com)
}

KeY WoRDS : Women in agriculture, Key developments, Thrust area

\begin{abstract}
View Point Article : Waris, Amtul (2016). Women in agriculture: Key developments under eleventh five year plan and thrust areas of the twelfth plan. Internat. J. Home Sci. Extn. \& Comm. Manage., 3 (1): 37-41.
\end{abstract}

Article History : Received : 08.07.2015; Accepted : 30.12 .2015

\section{INTRODUCTION}

Women play a pivotal role in agriculture not only as agricultural labourers, co-farmers and family labourers but as managers of the farm and farm entrepreneurs. Women constitute a large number of the agricultural workforce, NSSO data for 2011-12 shows that only 59 per cent of all rural male workers are in agriculture, but 75 per cent of all rural female workers are in agriculture. Moreover, the involvement of women in the agriculture sector is more even in the urban areas. It is 11 per cent as against that of 6 per cent for men. However, women in agriculture face several challenges of low or no land rights, authority, access to or control over resources required for enhancing production and household income. It is thus essential to look at the gender dimensions in agriculture. Several forward looking initiatives were taken up in the preceding five year plans of the country. This article envisages to summarise the initiatives of the Eleventh Five Year Plan and also highlight the initiatives and programs planned in the Twelfth Five Year Plan
(2012-17) for addressing the issues of women in agriculture.

\section{Participation in economy :}

The workforce participation rate for women at the national level as per Census 2011 was 25.51 per cent compared with 53.26 per cent for men. In the rural sector, the workforce participation rate for women was 30.02 per cent compared to 53.03 per cent for men. In the urban sector, it is 15.44 per cent for women and 53.76 per cent for men. As per Census 2011, 41.1 per cent of women main and marginal workers are engaged as agricultural labourers, 24.0 per cent are cultivators, 5.7 per cent are household industry workers and 29.2 per cent are engaged in other works. Moreover, in 2011-12, the worker population ratio for females in rural sector was 24.8 and for males it was 54.3. In Urban sector, it was 14.7 for females and 54.6 for males. In the rural sector, 59.3 per cent females were self-employed, 5.6 per cent females had regular wage/salaried employment and 35.1 per cent females were casual labours compared 